\title{
Does Aid for Education Educate Children? Evidence from Panel Data
}

\author{
Axel Dreher, Peter Nunnenkamp, and Rainer Thiele
}

\begin{abstract}
Most of the aid effectiveness literature has focused on the potential growth effects of aggregate aid, with inconclusive results. Considering that donors have repeatedly stressed the multidimensionality of their objectives, a more disaggregated view on aid effectiveness is warranted. The impact of aid on education is analyzed empirically for almost 100 countries over 1970-2004. The effectiveness of sector-specific aid is assessed within the framework of social production functions. The Millennium Development Goals related to education, particularly the goal of achieving universal primary school enrollment, are considered as outcome variables. The analysis suggests that higher per capita aid for education significantly increases primary school enrollment, while increased domestic government spending on education does not. This result is robust to the method of estimation, the use of instruments to control for the endogeneity of aid, and the set of control variables included in the estimations. JEL codes: F35, O11, H52, I22
\end{abstract}

There is heated debate over whether foreign aid is effective in promoting economic development. According to Sen (2006) and Tarp (2006), Easterly's (2006) claim that aid has done "so much ill and so little good" obscures the fact that aid can work if done right. Dalgaard, Hansen, and Tarp (2004) find that overall aid has indeed been effective. Even recent surveys of the literature on aid and growth come to sharply opposing conclusions. While Doucouliagos and Paldam (2005) conclude that the aid effectiveness literature has failed to

Axel Dreher (corresponding author) is a senior researcher at the KOF Swiss Economic Institute, ETH Zurich, and a research affiliate at the Institute for Economic Research, Center for Economic Studies (CESifo), at the University of Munich; his email address is mail@axel-dreher.de. Peter Nunnenkamp is Head of the Research Area Global Division of Labour at the Kiel Institute for the World Economy; his email address is peter.nunnenkamp@ifw-kiel.de. Rainer Thiele is Head of the Research Area Poverty Reduction, Equity, and Development at the Kiel Institute for the World Economy; his email address is rainer.thiele@ifw-kiel.de. The authors thank Christian Conrad, Martin Gassebner, Katja Michaelowa, participants at a seminar at the Kiel Institute for the World Economy, and three anonymous referees for their useful comments and suggestions, and Michaela Rank for excellent research assistance. A supplemental appendix to this article is available at www://wber. oxfordjournals.org

THE WORLD BANK ECONOMIC REVIEW, VOL. 22, NO. 2, pp. 291-314

doi:10.1093/wber/lhn003

Advance Access Publication April 11, 2008

(C) The Author 2008. Published by Oxford University Press on behalf of the International Bank for Reconstruction and Development / THE WORLD BANK. All rights reserved. For permissions, please e-mail: journals.permissions@oxfordjournals.org 
establish that aid works, McGillivray and others (2005) stress that almost all research published since the late 1990s finds that it does.

What both camps tend to ignore is that different types of aid are unlikely to have the same economic effects on recipient countries. In much of the literature, it is still common to run panel regressions with aggregate aid flows as the explanatory variable. Work by Clemens, Radelet, and Bhavnani (2004) on short-impact aid has initiated a shift toward using disaggregated aid data.

It is open to debate whether a verdict on the effectiveness of aid can be reached at all as long as the analysis is restricted to the aid-growth nexus. Donors have repeatedly stressed that they pursue multiple objectives when granting aid (see, for example, Isenman and Ehrenpreis 2003). Specific-purpose aid intended to support donors' policy statements, including the empowerment of the poor through better education, tends to escape analyses narrowly focused on aid and growth.

Against this backdrop, it seems appropriate to pursue a different avenue for assessing the effectiveness of aid. This article focuses on more specific outcome variables than growth. It uses disaggregated aid data to investigate the link between aid granted to the education sector and education outcomes.

Education figures prominently among the Millennium Development Goals. Donors have committed themselves to helping countries achieve universal primary education by 2015 and eliminate gender disparities in education. To this end, donors have devoted an increasing share of aid resources to the education sector (Thiele, Nunnenkamp, and Dreher 2007).

Yet, it is open to debate whether more resources necessarily translate into better education outcomes or how aid can play a role in achieving universal primary education (Roberts 2003). The effectiveness of aid for education is assessed here within the framework of social production functions. The results show that higher per capita aid significantly increases primary school enrollment. This outcome is robust to the method of estimation and to the set of control variables included.

The article is organized as follows. Section I provides the analytical background and discusses the literature on aid and education. Section II addresses data issues. The method of estimation and main results are presented in Section III, and various tests for robustness are performed in Section IV. The article closes with some concluding remarks about the implications of the findings for policy and future research.

\section{Analytical Background and Relevant Literature}

A social production function with education-related outcomes as the left-hand-side variable is estimated in which aid for education enters as an explanatory variable. Schultz (1988) proposed a production-demand framework to model the educational system of countries in the 1980s. The concept of a social production function has also been used in the literature on the link 
between government expenditure and social outcomes. Hanushek (1995, p. 2) considers this concept to be "most appealing and useful" to assess the relation between school outcomes and measurable educational inputs. Recent examples following this approach include Bennell (2002), Roberts (2003), and Baldacci, Guin-Siu, and de Mello (2003).

While the exact specification of social production functions varies, the common feature is that it includes major demand and supply factors (Roberts 2003). For the production function for education, demand factors typically considered include per capita income (a proxy for household poverty), adult literacy (a proxy for the educational status of parents), the relative size of the school population, and the level of urbanization. The "price" of schooling also affects demand, although it is typically not included in empirical cross-country analyses because of lack of data. School fees are supposed to inhibit enrollment, which is why free universal primary education has been advocated (see, for example, Bruns, Mingat, and Rakotomalala 2003). ${ }^{1}$

Public spending on education figures prominently among the supply factors considered in social production functions. Other potentially relevant supply factors include the pupil-teacher ratio and the unit costs of education. The regression analysis conducted below extends the production function concept by adding aid for education as an additional supply factor.

Various studies find that demand factors explain most of the variance in school attendance (enrollment, completion rates) and educational attainment (youth literacy, test scores) across countries. Surveying the literature, Roberts (2003) concludes that per capita income tends to be the most powerful driving force of school performance; supply-side factors, in particular public expenditure on education, are statistically insignificant in most instances. ${ }^{2}$ Roberts' own cross-country regression analysis corroborates the finding of ineffective public expenditure and finds that adult literacy is the main demand-side factor. Clemens (2004) shows that school enrollment rises only slowly over time and that the impact of education policy is relatively small compared with that of long-term economic changes. ${ }^{3}$

Very few studies consider foreign aid for education as a possibly important supply-side factor in the production function; studies that do so (Michaelowa and Weber 2006; Wolf 2007) are inconclusive. The aid literature focuses on whether aid helps achieve economic and social objectives by providing

1. The success of the Mexican anti-poverty program Progresa, in which educational subsidies in the form of conditional transfer payments to poor families increased enrollment, provides evidence for this notion (Behrman, Sengupta, and Todd 2005).

2. See Clemens (2004) and the references given there. Cross-country studies include Filmer and Pritchett (1999), Mingat and Tan (2003), and Baldacci, Guin-Siu, and de Mello (2003).

3. While this rather bleak picture concerning the ability of government spending on education to raise education outcomes appears to represent the majority view in the literature, there are some notable exceptions, including Gupta, Verhoeven, and Tiongson (1999) and Baldacci and others (2004). 
additional resources for financing pro-poor expenditure and on the extent to which aid is fungible. Although Pettersson (2006) finds a high degree of fungibility, some other studies show the aid-expenditure link to be important. Gomanee and others (2003) and Mosley, Hudson, and Verschoor (2004) find that aid alleviates poverty through its effect on public expenditure. Gomanee and others (2005) reach the opposite conclusion in a more recent version of their article.

The effects of aid working through public expenditure could be captured by estimating a system of equations that includes a public expenditure equation with aid as one explanatory variable (Mosley, Hudson, and Verschoor 2004). ${ }^{4}$ However, such an approach suffers from several problems. It is conceptually demanding, because the specification of the equations should ideally be based on a complete theoretical model, and the determinants of all dependent variables would have to be included in the estimations. The more conventional approach of instrumenting potentially endogenous variables in the production function for education has the advantage that instruments need explain only some fraction of the variation in the instrumented variables.

Furthermore, the interpretation of coefficients in the public expenditure equation is plagued with problems, particularly regarding the aid coefficient. A coefficient that is not significantly different from zero does not necessarily imply that aid is highly fungible and that aid does not add to overall (foreign and domestic) resources devoted to education. This implication would hold only if (most) aid were accounted for in the public budget of the recipient country. ${ }^{5}$ However, project aid for education — the most important mode of aid delivery, at least until recently-often remains outside the budget (Roberts 2003). If all aid remain outside the budget, full fungibility implies an aid coefficient of -1 . As it is impossible to determine the proportion of aid outside and inside the budget, estimation of the public expenditure equation offers no meaningful insights. For this reason, estimating a system of equations is not the preferred option.

The approach taken here follows the seminal contribution of Borenszstein, de Gregorio, and Lee (1998) on the economic growth effects of foreign direct investment (FDI). They consider both foreign and domestic investment in assessing whether foreign investment is more productive in raising growth. Analogously, an enrollment equation is estimated here that includes both aid for education and government expenditure on education as explanatory variables.

Aid for education may be more effective in raising enrollment rates than government expenditure on education, for several reasons (Roberts 2003).

4. This approach was adopted in an earlier version of this article.

5. The authors thank an anonymous referee for alerting them to the critical importance of this assumption. 
First, at least 75 percent of government expenditure typically consists of teacher salaries, which were not covered by donors until recently (Michaelowa and Weber 2006). Donors provide aid for building schools, supplying teaching materials, improving school management, and reforming curricula, in the hope of improving the learning environment, the efficiency of schools, and the quality of education, which may provide stronger incentives to attend school.

Second, government expenditure on education is often biased against the poor, the population segment for which enrollment rates tend to be relatively low (Bennell 2002). This contrasts with donor strategies emphasizing poor and disadvantaged groups, in particular girls, for whom school attendance is often lower than for boys.

Third, leakage of local funds appears to be high (Reinikka and Svensson 2001) and capture by producers and privileged consumers to be common. External donors may succeed at least partly in mitigating leakage and capture of aid funds by not channeling aid through the public budget of the recipient country, by involving local authorities in aid allocation processes, and by increasingly applying performance-based allocation rules. Measures such as these are recent, however; before the 1990 Jomtien Conference, which emphasized the importance of universal primary education, donor support concentrated on higher levels of education (Thiele, Nunnenkamp, and Dreher 2007). Consequently, it remains an empirical question whether foreign aid has been more effective than domestic public spending on education in promoting primary school enrollment.

\section{DAta Issues}

The data for assessing the impact of aid for education on education outcomes are far from perfect. The aid data-on commitments of sector-specific aid, including aid for education-come from the Creditor Reporting System (CRS) of the Organisation for Economic Co-operation and Development/ Development Assistance Committee (OECD/DAC). These data are imperfect because commitment data tend to overstate actual aid flows (commitments may not be fully disbursed) and because sector-specific commitments go partly unreported (Michaelowa and Weber 2006). These measurement problems, which work in opposite directions, cannot be resolved, because sector-specific disbursement data are not available before 1990. The correlation between commitments and disbursements of aid for education over the period for which both series are available is fairly high, with correlation coefficients of 0.70 for 1990-94, 0.71 for 1995-99, and 0.80 for 2000-04.

It can be argued that employing sector-specific aid data understates the contribution of aid to education objectives in recent years. Several donors now favor general budget support over project aid for specific targets. The extent to which general budget support is ultimately used for educational objectives is not known. 
A similar argument can be made about multisector aid. However, the evaluation of the composition of aid in Thiele, Nunnenkamp and Dreher (2007) suggests that this is unlikely to pose serious problems. In contrast to donor announcements, the shares of general budget support and multisector aid in total aid were actually lower in 2002-04 than in the early 1990s. Nevertheless, the robustness of results is checked by replicating the estimates for a shorter period of observation (excluding recent years, in which donors may have increasingly supported educational objectives through aid that is not picked up in sector-specific aid data).

Data limitations with respect to education outcome variables are well known (Roberts 2003; Bennell 2002). Ideally, the outcome variable of the production function should go beyond enrollment rates to include educational attainment and the quality of education. Enrollment rates may provide a misleading picture. Clemens (2004) draws on detailed country studies to show that rising enrollment rates came at the cost of deteriorating quality of education in some countries, as reflected by much higher pupil-teacher ratios, higher failure and repetition rates, and lower test scores. Furthermore, some countries report unreasonably high net enrollment ratios (more than 100).

Qualitative dimensions of education, such as improved literacy and test scores, are not available for a sufficiently large number of countries over a sufficiently long period of time. However, distortions resulting from the shortcomings of enrollment rates as an education outcome variable were minimized in several ways. First, completion rates were considered as an alternative indicator. Second, near universal enrollment rates were checked against reported ratios of boys to girls (enrollment rates of almost 100 percent are inconsistent with gender imbalance): except in Tajikistan, no major discrepancy was detected. Third, additional estimates were run for a reduced sample, eliminating countries with exceptionally large increases in enrollment rates.

Another data problem concerns the time-series dimension. In 2003, the United Nations Educational, Scientific, and Cultural Organization (UNESCO), the original source of the World Bank data used here, revised its estimates of net primary enrollment for 1998-2001. For some countries, this revision is associated with a major break in the series on primary enrollment. These countries were identified by comparing the old and new data in years for which both series are available (normally 1998-2000) (see Clemens 2004 for a similar approach). Discrepancies were minor (less than 2 percentage points) in 69 of the 119 sample countries for which this comparison was possible. The revision resulted in major discrepancies (more than 10 percentage points) in 15 countries, in 8 of which the old series appears to have overstated enrollment rates. This problem was dealt with in the tests for robustness by replicating the analysis for a shorter period of observation, 1970-97. In this way, the risk of inconsistencies over time can be reduced, even though the old series may suffer from systematic over- or underreporting by some countries. 


\section{Method of Estimation and Base Results}

Net primary school enrollment is the dependent variable throughout this section. The main explanatory variables of interest are aid to the education sector and government spending on education. (Using aid and spending on primary education is conceptually superior but would leave an insufficient number of observations for estimation.) Aid and government expenditure are measured on a per capita basis. In aid-growth regressions, aid is typically defined relative to the recipient country's gross domestic product (GDP). This provides a reasonable measure of the importance of foreign support relative to the recipient country's overall resources. Aid per capita is more appropriate than the aid to GDP ratio in assessing aid effectiveness with respect to specific Millennium Development Goals. In particular, achieving universal primary education requires accounting for the number of people among whom the resources devoted to education must be shared.

For other relevant covariates, the analysis closely follows the literature on education production functions in considering four demand-side variables: adult literacy, per capita GDP, ${ }^{6}$ share of the population under 15 , and share of the urban population in total population. Lagged education outcome is included as an additional explanatory variable in order to account for the possible persistence in outcomes. Additional supply-side variables suggested in the literature are added later to test for the sensitivity of results.

Pooled time-series cross-section (panel data) regressions are estimated for a maximum of 96 low- and middle-income countries between 1970 and 2004 (with the exception of data on aid, which are available only since 1973). ${ }^{7}$ As some of the data are not available on an annual basis, all data are five-year averages. (The definitions of and sources for all variables are listed in table A-1; summary statistics are reported in table A-2.)

The basic equation takes the following form:

$$
\operatorname{school}_{i, t}=\alpha+\beta_{1} \operatorname{school}_{i, t-1}+\beta_{2} \operatorname{aid}_{i, t}+\beta_{3} \operatorname{spending}_{i, t}+\mathrm{BX}+\eta_{i}+\varepsilon_{i, t}
$$

where school $_{i, t}$ represents the logarithm of primary school enrollment in country $i$ in year $t$; $\operatorname{aid}_{i, t}$ is per capita foreign aid to the education sector; and spending $_{i, t}$ is per capita government expenditure on education. $\mathrm{X}$ is the vector of control variables, $\eta_{i}$ represents country fixed effects, and $\varepsilon_{i, t}$ represents the disturbance term.

The dependent variable, school $_{i, t}$, is limited by a lower bound of zero and an upper bound of 100 . The upper bound may lead to biased results in the sense

6. Following most earlier studies estimating social production functions (for example, Gupta, Verhoeven, and Tiongson 1999; Roberts 2003; and Michaelowa and Weber 2006), per capita GDP is measured in levels.

7. High-income countries were excluded because they receive no aid. The World Bank (2007) defines high-income countries as those with a 2005 GNI per capita of at least $\$ 10,726$. 
that aid can have little effect on enrollment in recipient countries with enrollment rates of close to 100 percent. $^{8}$ One way to deal with this problem is through logistic rather than log linear estimation (Fielding, McGillivray, and Torres 2005). A different route is taken here. While the analysis follows the standard approach of the literature, which includes enrollment either in levels or in logs, it tests robustness by excluding recipient countries where enrollment rates exceed a certain threshold and may thus bias results downward.

Aid cannot reasonably be expected to be exogenous to school enrollment: donors typically grant more aid to countries that are less developed. Nevertheless, as a first step fixed- and random-effects models that ignore the potential endogeneity are estimated before we present specifications that allow for the endogeneity of aid and government expenditure. ${ }^{9}$

The qualitative findings do not depend on the inclusion of random or fixed country effects. However, the random-effects specification is rejected in favor of the fixed-effects model (Hausman test, $P=0.00$ ), so only fixed-effects estimates are reported (table 1, column 1). An F-test also shows that fixed country effects cannot be omitted $(P=0.00)$. By contrast, fixed-period effects did not turn out to be significant, so the estimates do not include them.

The estimates reveal a considerable degree of inertia in primary school enrollment. The lagged dependent variable is highly significant. ${ }^{10}$ Clearly, it has some explanatory power, rendering insignificant most of the other covariates included in the regression. The fixed-effects model indicates that literacy, the share of the population under the age of 15 , and the degree of urbanization do not significantly affect enrollment. ${ }^{11}$

Most surprisingly perhaps, per capita GDP does not have the expected positive impact on school enrollment, even when per capita GDP is alternatively specified in logs (not shown). As noted earlier, cross-country evidence suggests that per capita income is an important determinant of enrollment. ${ }^{12}$ By contrast, the explanatory power of per capita GDP is rather weak in the few panel studies that have been conducted. The insignificance of per capita GDP in table 1 is similar to the results obtained by Michaelowa and Weber (2006) as

8. The authors thank an anonymous referee for pointing this out.

9. The estimator is biased and inconsistent in a short panel because of the inclusion of the lagged dependent variable and fixed- or random-country effects. The GMM estimator presented later takes this into account.

10. A second lag of the dependent variable turned out to be completely insignificant.

11. Estimates based on a panel-corrected standard error model (not shown) point to a very strong relation between adult literacy and enrollment across countries, corroborating the findings of Gupta, Verhoeven, and Tiongson (1999) and Roberts (2003).

12. Even among cross-country studies, there are notable exceptions. Gupta, Verhoeven, and Tiongson (1999) do not find a robust effect of per capita GDP on enrollment. Mingat and Tan (1998) show that the cross-country correlation between per capita GDP and education is relatively weak when higher-income countries are excluded from the calculation, as they are in this article. 
TABle 1. School Enrollment and per Capita Aid to Education, 1970-2004

\begin{tabular}{|c|c|c|c|c|}
\hline Variable & (1) & $(2)$ & (3) & (4) \\
\hline Lagged dependent & $0.38(3.82) * *$ & $0.65(6.99) * * *$ & $0.44(4.63) * * *$ & $0.40(3.52) * *$ \\
\hline Expenditure on education (per capita) & $0.000034(0.37)$ & $-0.000198(1.47)$ & $0.000220(0.75)$ & $0.001523(1.04)$ \\
\hline Aid for education (per capita) & $0.0026(2.89) * * *$ & $0.0029(2.34) * *$ & $0.0268(2.69) * *$ & $0.0243(2.24) * *$ \\
\hline Literacy rate & $0.0034(1.35)$ & $0.0019(1.75) *$ & $0.0046(1.19)$ & $0.0081(1.43)$ \\
\hline GDP per capita & $-0.000003(0.61)$ & $0.000008(1.42)$ & $0.000028(1.29)$ & $0.000003(0.08)$ \\
\hline Population under 15 & $0.001(0.34)$ & $0.001(0.88)$ & $0.019(2.16) * *$ & $0.020(2.17) * *$ \\
\hline Urbanization & $-0.00022(0.09)$ & $-0.00015(0.30)$ & $0.00420(0.97)$ & $0.00035(0.05)$ \\
\hline Number of observations & 267 & 267 & 156 & 156 \\
\hline Maximum number of periods & 6 & 4 & 4 & 4 \\
\hline Method & Fixed effects & System GMM & 2SLS & 2SLS \\
\hline$R$-squared (overall) & 0.93 & & 0.41 & 0.40 \\
\hline Number of instruments & & 53 & 9 & 9 \\
\hline Hansen test $\left(\right.$ Prob $\left.>\chi^{2}\right)$ & & 0.60 & 0.11 & 0.14 \\
\hline Difference-in-Sargan test $\left(\right.$ Prob $\left.>\chi^{2}\right)$ & & 0.17 & & \\
\hline Arellano-Bond test $($ Prob $>z)$ & & 0.24 & & \\
\hline
\end{tabular}

Note: Numbers in parentheses are $t$-statistics, estimated robustly. The dependent variable is the logarithm of primary school enrollment in country $i$ at year $t$.

*Significant at the 10 percent level.

$*$ Significant at the 5 percent level.

$* * *$ Significant at the 1 percent level.

Source: Authors' analysis based on data described in table A-1. 
well as Baldacci and others (2004). ${ }^{13}$ The weak explanatory power of per capita GDP in panel studies may at least partly reflect the fact that these studies capture short- to medium-run effects through the time dimension, whereas the effects in cross-section analyses are purely long term.

The results show a positive correlation between aid and school enrollment, with coefficients significant at the 1 percent level. As in much of the previous literature, government expenditure on education does not affect enrollment significantly. Because both government expenditure and aid enter the regression, the significant coefficient of aid suggests that it is more productive than domestic government spending in raising school enrollment.

In the next step, the potential endogeneity of aid and government expenditure is taken into account (columns 2-4), starting with the system generalized method of moments (GMM) estimator, as suggested by Arellano and Bover (1995) and Blundell and Bond (1998). The dynamic panel GMM estimator exploits an assumption about the initial conditions to obtain moment conditions that remain informative even for persistent data and is considered most appropriate in the presence of endogenous regressors. Results are based on the two-step estimator implemented by Roodman (2005) in Stata, including Windmeijer's (2005) finite sample correction. Aid and government expenditure are treated as endogenous and the additional covariates as strictly exogenous. The validity of these assumptions was tested by applying the Hansen test (amounting to a test for the exogeneity of the covariates) and the Arellano-Bond test of second-order autocorrelation, which must be absent from the data for the estimator to be consistent. Both tests turned out to be borderline when the first lags of the aid variable and the dependant variable are included as instruments. This may suggest that aid once lagged is endogenous and thus invalid as an instrument. Therefore, the first lags were excluded from the list of instruments. The test statistics do then clearly not reject the specification at conventional levels of significance. ${ }^{14}$ A difference-in-Sargan test was does also performed on the additional instruments in the system GMM. This test also does not reject the specification.

The results remain qualitatively unchanged when the system GMM estimator is employed (column 2 in table 1). ${ }^{15}$ Results obtained by rerunning the regression using the Arellano and Bond (1991) GMM difference estimator (not reported) corroborate the main results of the system GMM estimation, although the literacy rate no longer significantly affects school enrollment.

13. Baldacci and others (2004), who do not include aid as a regressor, find per capita GDP to be a significant determinant of enrollment only in some of their estimated equations.

14. Additional tests were performed for third- and fourth-order serial correlation, which does not seem to be present in the data.

15. Excluding the first lag of the endogenous variables reduces the number of instruments to 53 . The regression was replicated excluding the second and third lags to ensure that the results do not depend on this still substantial number of instruments. This step reduced the number of instruments to 28. The relevant test statistics do clearly not reject the specification, and the results are not affected. In particular, the difference-in-Sargan test $\left(\operatorname{Prob}>\chi^{2}\right)$ is 0.42 . 
Two-stage least squares (2SLS) regressions are estimated instrumenting for aid as an alternative procedure for addressing the endogeneity issue. The International Country Risk Guide, the Fraser index of economic freedom, and the mortality rate of children under age five serve as instruments. These variables-the first two proxies for governance, the third a proxy for needhave been shown to be related to aid allocations (McKinlay and Little 1977; Hout 2004; Thiele, Nunnenkamp, and Dreher 2007). They are indeed highly correlated with aid for education in the sample and not significantly correlated with school enrollment once the other relevant regressors are controlled for. ${ }^{16}$ Government expenditure on education is taken as an exogenous regressor in column 3; both government expenditure and aid are instrumented in column 4. The International Country Risk Guide index for ethnic tensions is used as an instrument for government expenditure on education. While the previous literature does not come up with reliable instruments for government spending (Feldmann forthcoming), ethnic tensions have been shown to affect expenditure. $^{17}$

The overidentifying restrictions are not rejected at conventional levels of significance, suggesting that the model is well specified, and there is no sign that the instruments are endogenous. The instruments are jointly significant at the 1 percent level in the first-stage regressions, indicating some power. However, the F-test statistic falls short of the rule of thumb threshold of 10 proposed by Staiger and Stock (1997). Nelson and Startz (1990) show that the distribution of the 2SLS estimator and the $t$-statistics are only poorly approximated by the asymptotic representation with weak instruments. This is likely to imply test statistics with nonnormal distributions, making 2SLS misleading (Staiger and Stock 1997). According to Cruz and Moreira (2005), weak instruments exacerbate the finite sample bias inherent in the 2SLS estimator. Given that the specifications include the lagged dependent variable, 2SLS estimations may also suffer from dynamic panel bias. These estimations, therefore, have to be interpreted with caution. As all relevant test statistics do not reject the GMM specification, the preferred results are those based on the GMM regression (column 2 of table 1 ).

The effect of aid for education on primary school enrollment remains positive and significant at least at the 5 percent level when the two instrumental variable techniques are used. The lagged dependent variable is significant at the 1 percent level; per capita GDP and urbanization are insignificant. As before, so is government expenditure on education. The results on adult literacy are mixed. The share of the population under 15 has a completely

16. Initially, a measure of democracy was also included in the list of instruments. However, given that democracy might be important for the effect of aid on enrollment (as argued below), only the former three variables are used. The results are not affected by this choice.

17. Von Hagen (2005) argues that ideological and ethnic divisions result in higher government spending because each segment of society tends to neglect the tax burden falling on other segments, exacerbating the common pool problem. 
insignificant impact when estimated with GMM and a positive and significant impact in the potentially misspecified 2SLS regressions. The 2SLS results may appear counterintuitive, because having a larger share of the population under 15 would put pressure on the education system and would thus be expected to reduce enrollment rates. However, the positive coefficient in the 2SLS estimation is in line with the empirical evidence reported by Schultz (1988), according to whom a larger share of school-age children affects various educational variables negatively but primary school enrollment positively.

The quantitative impact of aid on school enrollment is modest but not negligible. With aid measured in per capita terms and the dependent variable in logarithms, the GMM specification implies that a $\$ 1$ increase in aid (roughly equivalent to the increase in average aid for education between 1975-79 and 1980-84 across the sample countries) increases school enrollment by about 0.29 percent. School enrollment would increase by 1.5 percent if donors kept their promise to double aid efforts (from an average of $\$ 5$ per capita to the education sector in 2000-04). This increase is roughly equal to the increase in average enrollment between 1995-99 and 2000-04.

The fixed-effects estimate implies a slightly smaller increase in school enrollment, of about 0.26 percent for each additional dollar of aid. By contrast, the quantitative impact indicated by the 2SLS regressions appears to be unrealistically high, with an additional dollar of per capita aid raising school enrollment from 2.4 to 2.7 percent. ${ }^{18}$

For comparison, regressions were also run with aid and government expenditure measured as a percentage of GDP rather than in per capita terms. In the fixed-effects specification, the qualitative results are very similar: aid increases primary schooling at the 5 percent level of significance. In the preferred GMM specification, however, aid does not significantly affect school enrollment when measured as a percentage of GDP. This finding supports the reasoning that the aid to GDP ratio is not as good a measure for assessing aid effectiveness with respect to specific Millennium Development Goals as per capita aid. (The results are shown in table S-1 in the supplemental appendix to this article, available at http://wber.oxfordjournals.org/)

Given the inclusion of the lagged dependent variable, it is also possible to calculate the long-run effect of aid on school enrollment. The estimates reported in column 2 of table 1, the preferred GMM specification, and coefficients of 0.003 for aid and 0.65 for lagged aid suggest that the long-term effect of an additional dollar of per capita aid is to raise school enrollment about 0.8 percent. The analysis was replicated excluding the population under the age of 15 as well as urbanization and per capita GDP (both of which were insignificant in the preferred specifications). The results do not change qualitatively or quantitatively: aid still increases enrollment significantly under all 
specifications. Government expenditure on education remains completely insignificant (see table S-2 in the online supplemental appendix).

\section{Sensitivity Analysis}

This section presents extensions of and tests for robustness of the previous results, focusing on GMM specifications (table 2). ${ }^{19}$ It begins by considering different aid measures. Ideally, one would employ aid disbursements for primary or basic education. However, even commitment data on aid for primary education are scarce, leaving an insufficient number of observations for meaningful estimation. Disbursements of total aid for education are available only since 1990. Moreover, inspection of the data suggests substantial underreporting of disbursed aid for education by donors until recently. ${ }^{20}$ In light of considerable measurement error, it is not surprising that the coefficient of aid disbursements remains insignificant (column 1).

Total aid disbursements, for which data are available for the entire period of observation, can be used instead of aid for education (column 2). But this aid variable also turns out to be insignificant in both the fixed-effects and GMM specifications. The finding that total aid has no impact on enrollment is not surprising, as aid for education, albeit of rising relative importance, accounted for just 8.2 percent of total aid in 2002-04 (Thiele, Nunnenkamp, and Dreher 2007).

School enrollment still rises with aid (at the 5 percent level of significance) when aid commitments per child below the age of 15 are used rather than commitments per capita (column 3). Primary completion rates have been suggested as superior to enrollment rates in measuring progress toward education-related Millennium Development Goals. However, data on primary completion are available only since 1988, reducing the sample size considerably. The small sample size may explain why aid for education does not significantly affect completion rates at conventional levels of significance (column 4).

In various other respects, the results prove fairly robust. In additional tests for robustness government expenditure on education is dropped from the equation, levels of school enrollment are used instead of logs, and the sample period is restricted to years before 1998. The concern that results may be biased because the dependent variable is bounded is addressed above, and two sets of outlying countries are omitted. The robustness of the results to the inclusion of additional variables suggested in the literature and to the exclusion of the lagged dependent variable is also tested. In most of these tests, the key result remains unaffected.

19. Corresponding fixed-effects estimates are shown in supplemental appendix table S-3.

20. Only in 2001-04 did disbursed aid exceed 50 percent of committed aid for education. Reported disbursements represented less than 10 percent of commitments in the early 1990 s. 
Taвle 2. School Enrollment and Aid: Tests for Robustness, System General Method of Moments, 1970-2004

\begin{tabular}{|c|c|c|c|c|c|c|c|c|c|c|c|c|c|c|c|}
\hline Variable & $\begin{array}{c}(1) \\
\text { School } \\
\text { enrollment }\end{array}$ & $\begin{array}{c}(2) \\
\text { School } \\
\text { enrollment }\end{array}$ & $\begin{array}{c}\text { (3) } \\
\text { School } \\
\text { enrollment }\end{array}$ & $\begin{array}{l}(4) \\
\text { Completion } \\
\text { rates }\end{array}$ & $\begin{array}{c}(5) \\
\text { School } \\
\text { enrollment }\end{array}$ & $\begin{array}{c}(6) \\
\text { School } \\
\text { enrollment } \\
\text { levels }\end{array}$ & $\begin{array}{c}(7) \\
\text { School } \\
\text { enrollment } \\
1970-97\end{array}$ & $\begin{array}{c}(8) \\
\text { School } \\
\text { enrollment }\end{array}$ & $\begin{array}{c}(9) \\
\text { School } \\
\text { enrollment }\end{array}$ & $\begin{array}{c}(10) \\
\text { School } \\
\text { enrollment }^{\mathrm{c}}\end{array}$ & $\begin{array}{c}\text { (11) } \\
\text { School } \\
\text { enrollment }\end{array}$ & $\begin{array}{c}\text { (12) } \\
\text { School } \\
\text { enrollment }\end{array}$ & $\begin{array}{c}\text { (13) } \\
\text { School } \\
\text { enrollment }\end{array}$ & $\begin{array}{c}(14) \\
\text { School } \\
\text { enrollment }\end{array}$ & $\begin{array}{c}(15) \\
\text { School } \\
\text { enrollment }\end{array}$ \\
\hline Lagged dependent & $\begin{array}{c}0.845 \\
(7.36)^{* * * *}\end{array}$ & $\begin{array}{l}0.530 \\
(5.40)^{* * * *}\end{array}$ & $\begin{array}{c}0.65 \\
(8.46)^{* * * *}\end{array}$ & $\begin{array}{l}0.821 \\
(8.30)^{* * * * *}\end{array}$ & $\begin{array}{l}0.603 \\
(5.20)^{* * * *}\end{array}$ & $\begin{array}{l}0.516 \\
(4.46)^{* * * *}\end{array}$ & $\begin{array}{l}0.617 \\
(6.42)^{* * * *}\end{array}$ & $\begin{array}{l}0.574 \\
(7.48)^{* * * * *}\end{array}$ & $\begin{array}{l}0.588 \\
(5.98)^{* * * *}\end{array}$ & $\begin{array}{l}0.617 \\
(6.42)^{* * * *}\end{array}$ & $\begin{array}{l}0.631 \\
(5.26)^{* * * *}\end{array}$ & $\begin{array}{l}0.626 \\
(6.33)^{* * * *}\end{array}$ & $\begin{array}{c}0.602 \\
(7.05)^{* * * *}\end{array}$ & $\begin{array}{l}0.594 \\
(5.47)^{* * * *}\end{array}$ & $\begin{array}{l}0.597 \\
(6.50)^{* * * *}\end{array}$ \\
\hline $\begin{array}{l}\text { Expenditure on } \\
\text { education (per } \\
\text { capita) }\end{array}$ & $\begin{array}{c}-0.00006 \\
(0.60)\end{array}$ & $\begin{array}{l}0.00007 \\
(0.69)\end{array}$ & $\begin{array}{c}-0.00009 \\
(1.21)\end{array}$ & $\begin{array}{l}0.00023 \\
(1.41)\end{array}$ & & $\begin{array}{c}-0.00102 \\
(0.16)\end{array}$ & $\begin{array}{c}-0.00008 \\
(0.94)\end{array}$ & $\begin{array}{c}-0.00534 \\
(0.73)\end{array}$ & $\begin{array}{c}-0.00004 \\
(0.57)\end{array}$ & $\begin{array}{c}-0.00008 \\
(0.94)\end{array}$ & $\begin{array}{c}-0.00001 \\
(0.10)\end{array}$ & $\begin{array}{c}-0.00002 \\
(0.24)\end{array}$ & $\begin{array}{c}-0.00005 \\
(0.74)\end{array}$ & $\begin{array}{c}-0.00010 \\
(1.16)\end{array}$ & $\begin{array}{c}-0.00009 \\
(1.07)\end{array}$ \\
\hline $\begin{array}{l}\text { Aid for education, } \\
\text { disbursements } \\
\text { (per capita) }\end{array}$ & $\begin{array}{l}0.0033 \\
(0.89)\end{array}$ & & & & & & & & & & & & & & \\
\hline $\begin{array}{l}\text { Total aid } \\
\text { disbursements } \\
\text { (per capita) }\end{array}$ & & $\begin{array}{l}0.00004 \\
(0.32)\end{array}$ & & & & & & & & & & & & & \\
\hline $\begin{array}{l}\text { Aid for education } \\
\text { commitments } \\
\text { (per child) }\end{array}$ & & & $\begin{array}{l}0.0008 \\
(2.47)^{* * *}\end{array}$ & & & & & & & & & & & & \\
\hline $\begin{array}{l}\text { Aid for education } \\
\text { commitments } \\
\text { (per capita) }\end{array}$ & & & & $\begin{array}{c}-0.002 \\
(0.46)\end{array}$ & $\begin{array}{l}0.002 \\
(2.10)^{* * *}\end{array}$ & $\begin{array}{c}0.182 \\
(1.79)^{* *}\end{array}$ & $\begin{array}{l}0.003 \\
(2.11)^{* * *}\end{array}$ & $\begin{array}{c}0.004 \\
(1.75)^{*}\end{array}$ & $\begin{array}{c}0.002 \\
(1.79)^{*}\end{array}$ & $\begin{array}{l}0.003 \\
(2.11)^{* * *}\end{array}$ & $\begin{array}{l}0.002 \\
(3.37)^{* * * *}\end{array}$ & $\begin{array}{l}0.003 \\
(2.54)^{* * * *}\end{array}$ & $\begin{array}{c}0.001 \\
(0.29)\end{array}$ & $\begin{array}{l}0.003 \\
(2.51)^{* * *}\end{array}$ & $\begin{array}{c}0.009 \\
(0.97)\end{array}$ \\
\hline Literacy rate & $\begin{array}{r}0.001 \\
(0.52)\end{array}$ & $\begin{array}{c}0.003 \\
(2.55)^{* * *}\end{array}$ & $\begin{array}{l}0.002 \\
(2.28)^{* * *}\end{array}$ & $\begin{array}{r}0.001 \\
(0.78)\end{array}$ & $\begin{array}{c}0.002 \\
(1.72)^{*}\end{array}$ & $\begin{array}{c}0.224 \\
(2.77)^{* * * *}\end{array}$ & $\begin{array}{l}0.002 \\
(2.23)^{* * *}\end{array}$ & $\begin{array}{l}0.002 \\
(2.30)^{* * *}\end{array}$ & $\begin{array}{c}0.003 \\
(2.27)^{* * *}\end{array}$ & $\begin{array}{l}0.002 \\
(2.23)^{* * *}\end{array}$ & $\begin{array}{l}0.002 \\
(2.65)^{* * *}\end{array}$ & $\begin{array}{c}0.003 \\
(2.30)^{* * *}\end{array}$ & $\begin{array}{l}0.003 \\
(2.19)^{* * *}\end{array}$ & $\begin{array}{l}0.003 \\
(2.23)^{\text {*** }}\end{array}$ & $\begin{array}{c}0.003 \\
(2.43)^{* * *}\end{array}$ \\
\hline Pupil-teacher ratio & & & & & & & & & & & $\begin{array}{l}4.13 \mathrm{E}-04 \\
(0.23)\end{array}$ & & & & \\
\hline $\begin{array}{l}\text { Unit costs of } \\
\text { enrollment }\end{array}$ & & & & & & & & & & & & $\begin{array}{r}-0.002 \\
(1.63)\end{array}$ & & & \\
\hline Aid-squared & & & & & & & & & & & & & $\begin{array}{l}0.00003 \\
(0.61)\end{array}$ & & \\
\hline International crisis & & & & & & & & & & & & & & $\begin{array}{c}0.16 \\
(1.91)^{*}\end{array}$ & \\
\hline Democracy & & & & & & & & & & & & & & & $\begin{array}{c}0.004 \\
(0.60)\end{array}$ \\
\hline
\end{tabular}




\begin{tabular}{|c|c|c|c|c|c|c|c|c|c|c|c|c|c|c|c|}
\hline Democracy"aid & & & & & & & & & & & & & & & $\begin{array}{r}-0.001 \\
(0.78)\end{array}$ \\
\hline Number of countries & 94 & 96 & 96 & 92 & 99 & 96 & 96 & 90 & 87 & 96 & 89 & 95 & 96 & 96 & 96 \\
\hline $\begin{array}{l}\text { Number of } \\
\text { observations }\end{array}$ & 199 & 269 & 269 & 194 & 306 & 269 & 269 & 221 & 238 & 269 & 176 & 268 & 269 & 269 & 269 \\
\hline $\begin{array}{l}\text { Maximum number of } \\
\text { periods }\end{array}$ & 3 & 6 & 6 & 3 & 6 & 6 & 6 & 6 & 6 & 6 & 3 & 6 & 6 & 6 & 6 \\
\hline $\begin{array}{l}\text { Number of } \\
\text { instruments }\end{array}$ & 21 & 42 & 42 & 24 & 36 & 42 & 42 & 42 & 42 & 42 & 34 & 43 & 62 & 62 & 44 \\
\hline $\begin{array}{l}\text { Hansen test } \\
\qquad\left(\operatorname{Prob}>\mathrm{chi}^{2}\right)\end{array}$ & 0.14 & 0.58 & 0.35 & 0.43 & 0.25 & 0.32 & 0.42 & 0.31 & 0.45 & 0.42 & 0.34 & 0.43 & 0.39 & 0.43 & 0.30 \\
\hline $\begin{array}{l}\text { Differences-in-Sargan } \\
\text { test }\left(\text { Prob }>\text { chi }^{2}\right)\end{array}$ & 0.06 & 0.92 & 0.13 & 0.94 & 0.28 & 0.19 & 0.41 & 0.21 & 0.40 & 0.21 & 0.24 & 0.18 & 0.73 & 0.16 & 0.25 \\
\hline $\begin{array}{l}\text { Arellano-Bond test } \\
\quad(\text { Prob }>z)\end{array}$ & & 0.12 & 0.18 & . & 0.06 & 0.61 & 0.19 & 0.29 & 0.82 & 0.19 & . & 0.20 & 0.19 & 0.28 & 0.18 \\
\hline
\end{tabular}

Note: Numbers in parentheses are $t$-statistics, estimated robustly. The dependent variable is in logarithms.

"Significant at the 10 percent level.

* :Significant at the 5 percent level.

***Significant at the 1 percent level.

${ }^{a}$ Excludes countries in the highest enrollment quartile.

${ }^{b}$ Excludes Botswana, Indonesia, Malawi, Rwanda, Togo, and Uganda (poor countries for which enrollment rates have risen particularly rapidly, according to Clemens 2004).

${ }^{c}$ Excludes Angola, Kuwait, Liberia, Lesotho, Malawi, and Tanzania (reported enrollment rates increased by more than 20 percent in a single year and

by 10 percentage points at least once over the period under consideration).

Source: Authors' analysis based on data described in table A-1. 
The reason to exclude government expenditure on education is that the aid coefficient may be biased downward when government expenditure is included and (part of) aid runs through the budget. The aid coefficient is supposed to capture the expenditure-augmenting effect of aid in addition to effects on enrollment that are attributable to a higher productivity of aid relative to government expenditure. The fact that the coefficient of aid is hardly affected when comparing column 5 in table 2 with column 2 in table 1 suggests that the expenditure-increasing effect of aid is not relevant, either because aid is not accounted for in the budget or because it is highly fungible.

Using enrollment levels instead of logs (column 6) leaves aid significant at the 10 percent level. One additional dollar of per capita aid increases school enrollment by about 0.2 percentage points. The years after 1997 are excluded because the results may be distorted by the revision of educational data since 1998 and by the recent shift from sector-specific aid, including aid for education, toward general budget support and multisector aid. Yet the key result is not affected: aid increases enrollment at the 5 percent level of significance (column 7).

The results reported in column 8 are based on a restricted sample that excludes all countries in the highest quartile in enrollment rates. In this way, a check can be run to determine whether the upper bound of the dependent variable implies a downward bias for aid effectiveness when including recipient countries with enrollment rates already close to 100 percent. The aid coefficient turns out to be somewhat larger for the restricted sample compared with column 2 in table 1 . The same pattern applies to the fixed-effects estimates (column 8 in supplemental appendix table S-3 and column 1 in table 1 ). Standard errors are larger for the restricted sample, which is not surprising given the smaller variance of enrollment rates and the smaller number of observations.

Next some potentially influential outliers are excluded, though to little effect. Botswana, Indonesia, Malawi, Rwanda, Togo, and Uganda are treated as outliers (column 9). Clemens (2004) identifies these countries as examples of poor countries for which enrollment rates reported by UNESCO have risen particularly rapidly, at least in some cases at the cost of deteriorating education quality (as reflected in high failure and repetition rates in Rwanda and Togo, steeply rising pupil-teacher ratios in Malawi, and lower test scores in Uganda). Alternatively, Angola, Kuwait, Liberia, Lesotho, Malawi, and Tanzania are excluded (column 10), because reported enrollment rates increased by more than 20 percent in a single year and by 10 percentage points at least once over the period under consideration. ${ }^{21}$ 
Alternative specifications include the pupil-teacher ratio, the unit cost of education (government expenditure on education divided by the population under 15, as a percent of per capita GDP), and a dummy variable for a crisis of international scale in the recipient country as additional control variables (columns 11, 12, and 14). The pupil-teacher ratio and the unit cost of production are applied as additional supply factors in the social production function framework. ${ }^{22}$ The dummy variable for international crisis is included because enrollment might be expected to decline in such years and crises might be correlated with aid.

With the exception of the crisis dummy variable, none of the additional variables is significant at conventional levels. In all cases, the impact of aid remains significant at the 5 percent level. Aid-squared has often been used in the literature on aid and growth (see, for example, Dalgaard, Hansen, and Tarp 2004), because aid may suffer from decreasing returns once its optimal degree is exceeded. Thus aid-squared is included in column 15. Although aid and aid-squared are not individually significant, they are jointly significant at the 5 percent level.

Finally, the possibility that the impact of aid on school enrollment might depend on democratic governance in the recipient countries is taken into account. This issue relates to the ongoing discussion of whether donors should target aid to better-governed countries. According to Svensson (1999), democratic institutions provide an institutionalized check on governments, encouraging them to use aid more productively. The impact of aid on education outcomes is thus hypothesized to be greater the greater the degree of democracy. The test of whether aid is more effective under conditions of good governance treats governance as exogenous to aid, which is in line with much of the previous literature. ${ }^{23}$ The interaction between aid and democracy is supposed to reveal a differential impact of aid. As a proxy for democratic governance, an index is constructed with data provided by Freedom House (2004). Data on this variable are available for a large number of countries and over most of the years under study.

While foreign aid does not increase enrollment individually in a significant way, aid and its interaction with democracy are jointly significant at the 10 percent level (column 15). The level of democracy and its interaction with aid are neither individually nor jointly significant at conventional levels.

22. Ideally, one would also want to control for the "price" of schooling. The lack of data does not permit this to be done.

23. The seminal contribution of Burnside and Dollar (2000) triggered the debate on whether aid is more effective under good policy conditions, treating the policy variables (openness, inflation, budget surplus) as exogenous. In a subsequent article, Burnside and Dollar (2004, p. 4) note that "researchers coming from the left, the right, and the center have all concluded that aid as traditionally practiced has not had systematic, beneficial effects on institutions and policies." Clemens, Radelet, and Bhavnani (2004) use instruments for institutional and policy variables; their use does not affect their results significantly. 
It therefore appears that, in contrast to the hypothesis derived by Svensson (1999), the impact of aid does not depend on democracy. Aid for education may help achieve universal education even in countries characterized by less-advanced democratic institutions. Whether this result is robust to the specification of the model and the measurement of democracy is an interesting question for future research. ${ }^{24}$

\section{Conclusions}

The effectiveness of sector-specific aid on education is assessed empirically within the framework of social production functions for almost 100 developing economies over the period 1970-2004, with the education Millennium Development Goals, particularly primary school enrollment, considered as outcome variables. The results suggest that higher per capita aid significantly increases primary school enrollment and domestic government spending on education does not. This result is robust to the method of estimation, the inclusion of instruments to control for the endogeneity of aid, and the set of control variables included in the estimations.

These findings are in sharp contrast to Easterly's (2006) verdict that foreign aid has done "so little good." At the same time, the analysis underscores the need to disaggregate aid in order to assess its effectiveness. Aid specifically devoted to the education sector modestly but not negligibly contributes to achieving universal primary education in developing economies. The preferred (GMM) specification (column 2 in table 1 ) implies that an additional dollar of per capita aid to the education sector increases school enrollment by about 0.3 percent. Consequently, school enrollment could improve considerably if donors kept their promise to double current aid efforts.

Aid that is effective in improving education should also have favorable longterm effects on economic growth, which might not be measurable with conventional econometric methods. ${ }^{25}$ But even if the link between education and growth turned out to be weak, the improved education outcome would be important in its own right, because "schooling has a large number of direct beneficial effects beyond raising economic output, such as lower child mortality" (Pritchett 2001, p. 388).

The positive effects of aid on education outcomes in recipient countries notwithstanding, the analysis points to some caveats that donors should keep in mind when giving aid. In contrast to some other studies (Gomanee and others 2003; Mosley, Hudson, and Verschoor 2004), this study finds no evidence that aid works by increasing government spending on education. Estimates are

24. In column 16 of supplemental appendix table S-3, results are also reported after omitting the lagged dependent variable from the fixed-effects specification. The main result is unchanged. Under this specification, the literacy rate positively affects enrollment, with a highly significant coefficient.

25. The longer-term growth effects of aid are difficult if not impossible to capture, as Clemens, Radelet, and Bhavnani (2004) argue. For a different view, see Rajan and Subramanian (2005). 
hardly affected when accounting for both the productivity-enhancing and the expenditure-augmenting effects of aid (by excluding government spending from the estimations). It remains open to debate whether this is mainly because donors deliberately decided to grant aid outside the budget or because aid was highly fungible in the past. This question may be resolved in future research if donors increasingly shift from project-related aid to general budget support. For the time being, the complete insignificance of government spending on education in the estimations cautions against expecting too much from the "new form of conditionality" proposed by Mosley, Hudson, and Verschoor (2004). It remains to be seen whether the ability to use aid for education as a means of strengthening the poverty orientation of government spending on education has improved with the advent of Poverty Reduction Strategy Papers.

Lacking conclusive evidence that conditionality works donors should be selective when determining the allocation of aid for education. The most obvious criterion for selectivity is the need for aid in education, as reflected in particularly low enrollment and completion rates. The targeting of aid for education according to need leaves much to be desired, as Thiele, Nunnenkamp, and Dreher (2007) show.

Another selectivity criterion stressed by many donors-the quality of governance in recipient countries-might be less important than widely believed. Investigation of this issue is left to future research.

Finally, it would be desirable to assess whether the effectiveness of aid for education could be enhanced by shifting donor resources within the sector toward basic education. Basic education accounted for about one-third of total aid for education by donors in 2002-04 (Thiele, Nunnenkamp, and Dreher 2007). This low level of spending is not only in conflict with Millennium Development Goal2, which would require greater concentration on basic education, but also with findings that social returns to primary education tend to be particularly high in low-income countries (World Bank 1995). Future research may be able to address this issue by disaggregating aid and education data more finely once longer time-series are available for a larger number of countries.

APPENDIX

Table A-1. Definitions and Sources

\begin{tabular}{llc}
\hline Variable & \multicolumn{1}{c}{ Description } & \multicolumn{1}{c}{ Source } \\
\hline School enrollment & $\begin{array}{l}\text { Ratio of number of children of official } \\
\text { school age enrolled in school to number } \\
\text { of children of official school age (net } \\
\text { enrollment ratio) }\end{array}$ & World Bank (2005) \\
\hline
\end{tabular}


Table A-1. Continued

\begin{tabular}{|c|c|c|}
\hline Variable & Description & Source \\
\hline Primary completion rate & $\begin{array}{l}\text { Number of students successfully } \\
\text { completing the last year of (or } \\
\text { graduating from) primary school in a } \\
\text { given year divided by the number of } \\
\text { children of official graduation age in } \\
\text { the population }\end{array}$ & World Bank (2005) \\
\hline Expenditure on education & $\begin{array}{l}\text { Public spending on public education plus } \\
\text { subsidies to private education at the } \\
\text { primary, secondary, and tertiary levels. } \\
\text { Variable measured both per capita and } \\
\text { as percent of GDP }\end{array}$ & $\begin{array}{l}\text { World Bank (2003, } \\
\text { 2005) }\end{array}$ \\
\hline $\begin{array}{l}\text { Aid for education } \\
\text { (commitments) }\end{array}$ & $\begin{array}{l}\text { Aid commitments by all donors according } \\
\text { to CRS Purpose Code } 110 \text {. Includes aid } \\
\text { for basic education, secondary } \\
\text { education, postsecondary education, } \\
\text { and unspecified levels of education. } \\
\text { CRS guidelines require sector-specific } \\
\text { program assistance and budget support } \\
\text { in the form of sector-wide approaches } \\
\text { to be subsumed under education when } \\
\text { meant to benefit this sector. Variable } \\
\text { measured both per capita, per child } \\
\text { below age } 15 \text {, and as percent of } \\
\text { recipient country's GDP }\end{array}$ & OECD (2006) \\
\hline $\begin{array}{l}\text { Aid for education } \\
\text { (disbursements) }\end{array}$ & $\begin{array}{l}\text { Aid disbursements by all donors } \\
\text { according to CRS Purpose Code } 110 \text {, } \\
\text { Form } 2 \text {. Coverage is same as for } \\
\text { commitments. Variable measured per } \\
\text { capita }\end{array}$ & OECD (2006) \\
\hline Total disbursements & $\begin{array}{l}\text { Total aid (in all sectors) disbursed by all } \\
\text { donors. Variable measured per capita }\end{array}$ & OECD (2006) \\
\hline Literacy rate & $\begin{array}{l}\text { Percentage of people } 15 \text { and older who } \\
\text { can, with understanding, read and write } \\
\text { a short simple statement on their } \\
\text { everyday life }\end{array}$ & World Bank (2005) \\
\hline GDP per capita & $\begin{array}{l}\text { Per capita GDP in purchasing power } \\
\text { parity terms ( } 2000 \text { international } \\
\text { dollars) }\end{array}$ & World Bank (2005) \\
\hline Population under 15 & Percentage of total population under 15 & World Bank (2005) \\
\hline Urbanization & $\begin{array}{l}\text { Share of total population living in areas } \\
\text { defined as urban in each country }\end{array}$ & World Bank (2005) \\
\hline Democracy index & $\begin{array}{l}{[8-(\text { political rights index }+ \text { civil liberties }} \\
\text { index })] / 2\end{array}$ & Freedom House (2004) \\
\hline Pupil-teacher ratio & $\begin{array}{l}\text { Number of pupils enrolled in primary } \\
\text { school divided by number of primary } \\
\text { school teachers (regardless of their } \\
\text { teaching assignment) }\end{array}$ & World Bank (2005) \\
\hline
\end{tabular}


TABle A-1. Continued

\begin{tabular}{|c|c|c|}
\hline Variable & Description & Source \\
\hline Unit costs of enrollment & $\begin{array}{l}\text { Government expenditure on education } \\
\text { divided by population under } 15 \text {, as } \\
\text { percent of per capita GDP }\end{array}$ & World Bank (2005) \\
\hline International crisis & $\begin{array}{l}\text { Dummy variable that takes value of } 1 \\
\text { when a country is involved in an } \\
\text { international crisis }\end{array}$ & $\begin{array}{l}\text { Wilkenfeld and Brecher } \\
\text { (2006) }\end{array}$ \\
\hline Government stability & $\begin{array}{l}\text { Assesses government's ability to carry out } \\
\text { its declared programs and its ability to } \\
\text { remain in office. Risk rating assigned is } \\
\text { sum of three subcomponents } \\
\text { (government unity, legislative strength, } \\
\text { popular support), each with a } \\
\text { maximum score of four points and a } \\
\text { minimum score of } 0 \text { points. A score of } \\
4 \text { points indicates very low risk and a } \\
\text { score of } 0 \text { points very high risk }\end{array}$ & ICRG (2005) \\
\hline Under-five mortality & $\begin{array}{l}\text { Probability that newborn baby will die } \\
\text { before reaching age five if subject to } \\
\text { current age-specific mortality rates. } \\
\text { Variable expressed as rate per } 1,000\end{array}$ & World Bank (2005) \\
\hline Economic Freedom & $\begin{array}{l}\text { Composite } 0-10 \text { index of economic } \\
\text { freedom; higher values reflect greater } \\
\text { freedom }\end{array}$ & $\begin{array}{l}\text { Gwartney and Lawson } \\
\text { (2004) }\end{array}$ \\
\hline
\end{tabular}

Source: Authors' description based on cited data sources.

Table A-2. Summary Statistics (Estimation Sample, Table 1, Column 2)

\begin{tabular}{lllll}
\hline Variable & Mean & Minimum & Maximum & $\begin{array}{l}\text { Standard } \\
\text { deviation }\end{array}$ \\
\hline School enrollment (logarithm) & 4.36 & 3.10 & 4.68 & 0.31 \\
Primary completion rate (logarithm) & 4.26 & 2.77 & 4.72 & 0.46 \\
Expenditure on education (per capita) & 95.78 & 3.56 & 697.50 & 111.94 \\
Expenditure on education (percent of GDP) & 4.28 & 0.83 & 11.58 & 1.88 \\
Aid for education, commitments (per capita) & 3.67 & 0.00 & 64.33 & 6.51 \\
Aid for education, commitments (percent of & 0.43 & 0.00 & 3.23 & 0.57 \\
$\quad$ GDP) & & & & \\
Aid for education, commitments per child & 10.56 & 0.00 & 292.84 & 22.38 \\
Aid for education, disbursements per capita & 0.86 & 0.00 & 21.90 & 1.90 \\
Total aid disbursements per capita & 33.50 & -2.34 & 304.07 & 37.50 \\
Literacy rate & 73.79 & 10.30 & 99.80 & 22.75 \\
GDP per capita & 4783 & 494 & 16050 & 3497 \\
Population under 15 & 36.89 & 15.02 & 51.09 & 8.62 \\
Urbanization & 48.16 & 5.14 & 92.63 & 21.55 \\
Democracy, index & 4.04 & 1.00 & 7.00 & 1.76 \\
Pupil-teacher ratio & 31.53 & 10.28 & 77.03 & 13.20 \\
International crisis & 0.07 & 0.00 & 0.80 & 0.16 \\
Unit costs of enrollment & 13 & 1.76 & 38 & 7 \\
Government stability & 7.84 & 2.28 & 11.08 & 1.78 \\
\hline
\end{tabular}


TABLE A-2. Continued

\begin{tabular}{lllll}
\hline Variable & Mean & Minimum & Maximum & $\begin{array}{l}\text { Standard } \\
\text { deviation }\end{array}$ \\
\hline Under-five mortality & 75.14 & 7.50 & 320.00 & 65.48 \\
Economic freedom & 5.76 & 2.90 & 7.50 & 0.98 \\
\hline
\end{tabular}

Source: Authors' analysis based on data described in table A-1.

\section{REFERENCES}

Arellano, Manuel, and Stephen Bond. 1991. "Some Tests for Specification for Panel Data: Monte Carlo Evidence and an Application to Employment Equations." Review of Economic Studies 58(2): 277-97.

Arellano, Manuel, and Olympia Bover. 1995. "Another Look at the Instrumental Variable Estimation of Error-components Models." Journal of Econometrics 68(1):29-51.

Baldacci, Emanuele, Maria Teresa Guin-Siu, and Luiz R. de Mello. 2003. "More on the Effectiveness of Public Spending on Health Care and Education: A Covariance Structure Model." Journal of International Development 15(6):709-25.

Baldacci, Emanuele, Benedict J. Clements, Sanjeev Gupta, and Qiang Cui. 2004. Aid, Social Spending, Human Capital, and Growth in Developing Countries: Implications for Achieving the MDGs. IMF Working Paper WP/04/217. Washington, D.C: International Monetary Fund.

Behrman, Jere, Piyali Sengupta, and Petra Todd. 2005. "Progressing through PROGRESA: An Impact Assessment of a School Subsidy Experiment in Rural Mexico." Economic Development and Cultural Change 54(1):237-75.

Bennell, Paul. 2002. "Hitting the Target: Doubling Primary School Enrollments in Sub-Saharan Africa by 2015." World Development 30(7):1179-94.

Blundell, Richard, and Stephen Bond. 1998. "Initial Conditions and Moment Restrictions in Dynamic Panel Data Models." Journal of Econometrics 87(1):115-43.

Borenszstein, Eduardo, R., José. de Gregorio, and Jong-Wha Lee. 1998. "How Does Foreign Direct Investment Affect Economic Growth?” Journal of International Economics 45(1):115-35.

Bruns, Barbara, Alain Mingat, and Ramahatra Rakotomalala. 2003. Achieving Universal Primary Education by 2015: A Chance for Every Child. Policy Research Working Paper. World Bank, Washington, D.C.

Burnside, Craig, and David Dollar. 2000. "Aid, Policies, and Growth." American Economic Review 90(4):847-68.

- 2004. Aid, Policies, and Growth: Revisiting the Evidence. Policy Research Working Paper 3251. World Bank, Washington, D.C.

Clemens, Michael A. 2004. The Long Walk to School: International Education Goals in Historical Perspective. Center for Global Development Working Paper 37. Washington, D.C.

Clemens, Michael A., Steven Radelet, and Rikhil Bhavnani. 2004. Counting Chickens When They Hatch: The Short-Term Effects of Aid on Growth. Center for Global Development Working Paper 44, Washington, D.C.

Cruz, Luiz M., and Marcelo J. Moreira. 2005. "On the Validity of Econometric Techniques with Weak Instruments: Inference on Returns to Education Using Compulsory School Attendance Laws." Journal of Human Resources 40(2):393-410.

Dalgaard, Carl-Johan, Henrik Hansen, and Finn Tarp. 2004. "On the Empirics of Foreign Aid and Growth.” Economic Journal 114(June):F191-216. 
Doucouliagos, Hristos, and Martin Paldam. 2005. The Aid Effectiveness Literature: The Sad Results of 40 Years of Research. Department of Economics Working Paper 2005.05. Denmark: University of Aarhus.

Easterly, William. 2006. The White Man's Burden: Why the West's Efforts to Aid the Rest Have Done So Much Ill and So Little Good. New York: Penguin Press.

Feldmann, Horst, "Government Size and Unemployment in Developing Countries." Forthcoming Applied Economics Letters.

Fielding, David, Mark McGillivray, and Sebastian Torres. 2005. "Synergies between Health, Wealth, Education, Fertility and Aid: Implications for Achieving the Millennium Development Goals.” World Institute for Development Economics Research, Helsinki. (www.wider.unu.edu/research/ 2004-2005/2004-2005-1/mdg-papers/fielding-mcgillivray-torres-160805.pdf).

Filmer, Deon, and Lant Pritchett. 1999. "The Effect of Household Wealth on Educational Attainment: Evidence from 35 Countries." Population and Development Review 25(1):85-120.

Freedom House. 2004. Annual Report. (www.freedomhouse.org).

Gomanee, Karuna, Oliver Morrissey, Paul Mosley, and Arjan Verschoor. 2003. "Aid, Pro-Poor Government Expenditure and Welfare.” CREDIT Research Paper 03/03. University of Nottingham, United Kingdom: Centre for Research in Economic Development and International Trade.

- 2005. “Aid, Government Expenditure, and Aggregate Welfare." World Development 33(3):355-70.

Gupta, Sanjeev, Marijn Verhoeven, and Erwin Tiongson. 1999. Does Higher Government Spending Buy Better Results in Education and Health Care? IMF Working Paper WP/99/21. Washington, D.C.: International Monetary Fund.

Gwartney, James D., and Robert A. Lawson. 2004. Economic Freedom of the World: 2004 Annual Report. Vancouver: Fraser Institute. (www.freetheworld.com).

Hanushek, Erik A. 1995. "Interpreting Recent Research on Schooling in Developing Countries." World Bank Research Observer 10(2):227-46.

Hout, Wil. 2004. "Political Regimes and Development Assistance: The Political Economy of Aid Selectivity." Critical Asian Studies 36(4):591-613.

ICRG (International Country Risk Guide). 2005. International Country Risk Guide Political Risk Indicator. (www.countryrisk.com/guide/archives/cat_country_risk_ratings.html).

Isenman, Paul, and Dag Ehrenpreis. 2003. "Results of the OECD DAC/Development Centre Experts' Seminar on 'Aid Effectiveness and Selectivity: Integrating Multiple Objectives into Aid Allocations.'” DAC Journal 4(3):7-25.

McGillivray, Mark, Simon Feeny, Niels Hermes, and Robert Lensink. 2005. “It Works; It Doesn't; It Can, But That Depends. 50 Years of Controversy over the Macroeconomic Impact of Development Aid.” Research Paper 2005/54. Helsinki: United Nations University, World Institute for Development Economics Research.

McKinlay, Robert D., and Richard Little. 1977. “A Foreign Policy Model of U.S. Bilateral Aid Allocation." World Politics 30(1):58-86.

Michaelowa, Katharina, and Anke Weber. 2006. "Aid Effectiveness Reconsidered: Panel Data Evidence for the Education Sector." HWWA Discussion Paper 264. Germany: Hamburg Institute of International Economics.

Mingat, Alain, and Jee-peng Tan. 1998. The Mechanics of Progress in Education: Evidence from Cross-Country Data. Policy Research Working Paper 2015, World Bank, Washington, D.C.

- 2003. "On the Mechanics of Progress in Primary Education." Economics of Education Review 22(5):455-67.

Mosley, Paul, John Hudson, and Arjan Verschoor. 2004. “Aid, Poverty Reduction, and the 'New Conditionality."” Economic Journal 114(496):F217-43.

Nelson, Charles R., and Richard Startz. 1990. "Some Further Results on the Exact Small Sample Properties of the Instrumental Variable Estimator.” Econometrica 58(4):967-76. 
OECD (Organisation for Economic Co-operation and Development). 2006. International Development Statistics (IDS) Online: Databases on Aid and Other Resource Flows. (www.oecd.org/dataoecd/50/ 17/5037721.htm).

Pettersson, Jan. 2006. "Foreign Sectoral Aid Fungibility, Growth and Poverty Reduction.” Paper presented at the World Institute for Development Economics Research Conference "Aid: Principles, Policies and Performance," June 16-17, Helsinki.

Pritchett, Lant. 2001. "Where Has All the Education Gone?" World Bank Economic Review 15(3):367-91.

Rajan, Raghuram G., and Arvind Subramanian. 2005. Aid and Growth: What Does the Evidence Really Show? IMF Working Paper WP/05/127. Washington, D.C.: International Monetary Fund.

Reinikka, Ritva, and Jacob Svensson. 2001. "Explaining Leakage of Public Funds.” WIDER Discussion Paper 2001/147, Helsinki: United Nations University, World Institute for Development Economics Research.

Roberts, John. 2003. Poverty Reduction Outcomes in Education and Health: Public Expenditure and Aid. ODI Working Paper 210. London: Overseas Development Institute.

Roodman, David. 2005. "Xtabond2: Stata Module to Extend Xtabond Dynamic Panel Data Estimator." Washington, D.C.: Center for Global Development.(http://econpapers.repec.org/software/ bocbocode/s435901.htm).

Schultz, T. Paul. 1988. "Expansion of Public School Expenditures and Enrollments: Intercountry Evidence on the Effects of Income, Prices, and Population Growth." Economics of Education Review 7(2):167-83.

Sen, Amartya. 2006. "The Man without a Plan.” Foreign Affairs (March/April). (www.nyu.edu/fas/ institute/dri/Easterly/File/Foreign \%20Affairs\%20-\%20The\%20Man\%20Without \%20a \%20Plan\% 20-\%20Amartya \%20Sen.pdf).

Staiger, Douglas, and James H. Stock. 1997. "Instrumental Variables Regression with Weak Instruments." Econometrica 65(3):557-86.

Svensson, Jacob. 1999. "Aid, Growth and Democracy.” Economics \& Politics 11(3):275-97.

Tarp, Finn. 2006. "Scaling Up Aid: Challenges and Opportunities: A Few Comments.” Paper presented at the World Institute for Development Economics Research Conference "Aid: Principles, Policies and Performance," June 16-17, Helsinki.

Thiele, Rainer, Peter Nunnenkamp, and Axel Dreher. 2007. "Do Donors Target Aid in Line with the Millennium Development Goals? A Sector Perspective of Aid Allocation." Review of World Economics 143(4):596-630.

Von Hagen, Juergen. 2005. “Political Economy of Fiscal Institutions.” GESY Discussion Paper 149. Germany: Mannheim University.

Wilkenfeld, Jonathan, and Michael Brecher. 2006. "International Crisis Behavior Project." Center for International Development and Crisis Management, College Park, MD, USA. (www.cidcm.umd. edu/icb).

Windmeijer, Frank. 2005. "A Finite Sample Correction for the Variance of Linear Efficient Two-Step GMM Estimators.” Journal of Econometrics 126(1):25-51.

Wolf, Susanna. 2007. "Does Aid Improve Public Service Delivery?" Review of World Economics 143(4):650-672.

World Bank. 1995. Development in Practice: Priorities and Strategies for Education. Washington D.C. 2003. World Development Indicators CD-ROM. 2005, and 2007 Washington, D.C. 